\title{
Spanning tussen het evenredigheidsbeginsel en het gelijkheids- en transparantiebeginsel bij het uitsluiten van ondernemingen in het aanbestedingsrecht
}

\author{
Mr. G. Bouwman*
}

In deze bijdrage staat het Connexxion Taxi Servicesarrest centraal, waarin het Hof van Justitie in een afweging tussen beginselen voorrang geeft aan het gelijkheids- en transparantiebeginsel boven het evenredigheidsbeginsel bij het uitsluiten van een onderneming van een aanbestedingsprocedure. Het Hof van Justitie benadrukt daarmee het belang van het 'level playing field' in het aanbestedingsrecht. Tegelijkertijd gaat dit hier ten koste van het evenredigheidsbeginsel dat een belangrijke rol speelt in de afweging of een uitsluiting van een onderneming met het oog op de internemarktdoelstelling gerechtvaardigd is. Het is echter de vraag in hoeverre het Hof van Justitie tot dezelfde beslissing zou komen onder de nieuwe Aanbestedingsrichtlijn 2014/24/EU.

Hvf 14 december 2016, zaak C-171/15, Connexxion Taxi Services, ECLI:EU:C:2016:948

\section{Inleiding}

Een van de meest voorkomende problemen bij de uitlegging van Richtlijn 2004/18/EG ${ }^{1}$ (hierna ook: de Aanbestedingsrichtlijn), betreft de bevoegdheid van de lidsta-

* Mr. G. Bouwman is promovenda Europees en internationaal aanbestedingsrecht aan de Universiteit Utrecht en onderzoeker bij het Public Procurement Research Centre. De auteur dankt prof. mr. E.R. Manunza voor haar waardevolle commentaar bij de totstandkoming van deze bijdrage.

1. Richtlijn van het Europees Parlement en de Raad van 31 maart 2004 betreffende coördinatie van de procedures voor het plaatsen van overheidsopdrachten voor werken, leveringen en diensten, PbEU 2004, L 134/114. Inmiddels vervangen door Richtlijn 2014/24/EU: Richtlijn van het Europees Parlement de Raad van 26 februari 2014 betreffende het plaatsen van overheidsopdrachten en tot intrekking van Richtlijn 2004/18/EG, PbEU 2014, L 94/65.

ten om bepaalde inschrijvers van een overheidsopdracht uit te sluiten. ${ }^{2}$ In het aanbestedingsrecht is in een uitsluitingsstelsel voorzien, met zowel verplichte als nietverplichte (facultatieve) uitsluitingsgronden. Op grond daarvan moeten ondernemingen bijvoorbeeld verplicht worden uitgesloten, wanneer zij zich hebben schuldig gemaakt aan deelname aan een criminele organisatie, witwassen van geld of omkoping. Daarnaast kunnen ondernemingen worden uitgesloten op basis van de in de lidstaten geïmplementeerde facultatieve gronden, als de aanbestedende dienst deze bij een concrete aanbesteding vooraf van toepassing heeft verklaard. Voorbeelden daarvan zijn uitsluiting op basis van een faillissement van de inschrijver of het hebben begaan van een ernstige fout in de uitoefening van het beroep. ${ }^{3}$

Ook in het arrest van 14 december 2016 (hierna: Connexxion Taxi Services-arrest) ${ }^{4}$ het arrest dat in deze bijdrage centraal staat, wordt het Hof van Justitie om verduidelijking gevraagd over deze bevoegdheid ondernemingen van een aanbestedingsprocedure uit te sluiten

2. Zoals ook A-G M. Campos Sánchez-Bordona vermeldt in de conclusie, overweging 1. Dit blijkt uit de vele arresten die het Hof van Justitie over dit onderwerp heeft gewezen. Enkele belangrijke arresten zullen hierna worden behandeld. Het uitsluitingssysteem is neergelegd in art. 57 van Richtlijn 2014/24/EU en voorheen - en in deze zaak - opgenomen in art. 45 Richtlijn 2004/18/EG

3. Onder Richtlijn 2004/18/EG opgenomen in art. 45. In art. 57 van de nieuwe Richtlijn 2014/24/EU zijn de uitsluitingsgronden in aantal toegenomen. Deze uitsluitingsgronden zijn nu geïmplementeerd in art. 2.86-2.88 van de Aanbestedingswet 2012, maar ten tijde van de situatie in onderhavig arrest neergelegd in art. 45 Besluit van 16 juli 2005 , houdende regels betreffende de procedures voor het gunnen van overheidsopdrachten voor werken, leveringen en diensten (Bao).

4. HvJ 14 december 2016, zaak C-171/15, Connexxion Taxi Services, ECLI:EU:C:2016:948. 
- de facultatieve uitsluitingsgronden. ${ }^{5}$ Bijzonder aan deze zaak is dat de kernvraag zich toespitst op een afweging tussen cruciale beginselen van het aanbestedingsrecht: het evenredigheidsbeginsel, hierna ook wel proportionaliteitsbeginsel - op grond waarvan uitsluiting van een aanbestedingsprocedure in beginsel slechts dient plaats te vinden als de concrete situatie uitsluiting vereist - en de beginselen van gelijkheid en transparantie die met het oog op het level playing field voor alle geinteresseerde ondernemingen, in beginsel vereisen dat uitsluiting plaatsvindt als dat in de aanbestedingsdocumenten $^{6}$ is opgenomen.

In deze bijdrage zal allereerst kort worden ingegaan op de feiten die aanleiding waren voor het stellen van de prejudiciële vragen. Alvorens dan in te gaan op de afweging die het Hof van Justitie in onderhavige zaak maakt, ten voordele van het gelijkheids- en transparantiebeginsel ten opzichte van het evenredigheidsbeginsel, zullen deze beginselen worden geplaatst in het licht van de uitgangspunten van het aanbestedingsrecht, in het bijzonder met betrekking tot het uitsluitingsstelsel. Aansluitend zal worden ingegaan op de gemaakte afweging door het Hof van Justitie, waarbij ook de conclusie van de advocaat-generaal wordt betrokken nu diens tegengestelde conclusie duidelijk laat zien dat deze afweging doorgaans zal resulteren in een voorrang van het evenredigheidsbeginsel. Vervolgens wordt aan de hand van de concrete omstandigheden van het geval bezien hoe het Hof van Justitie in het Connexxion Taxi Services-arrest tot zijn conclusie is gekomen. Tot slot zal de betekenis van dit arrest worden behandeld voor situaties onder het huidige rechtskader van Aanbestedingsrichtlijn 2014/24/EU.

\section{Aanleiding voor de prejudiciële} vragen

In deze zaak heeft het ministerie van Volksgezondheid, Welzijn en Sport (hierna: VWS) een anbesteding in de markt gezet, voor de 'dienstverlening sociaalrecreatief bovenregionaal vervoer voor mensen met een mobiliteitsbeperking'. Dit product, ook wel bekend onder de naam 'Valys', houdt in dat personen binnen de doelgroep een reisbudget aan taxikilometers krijgen, waar-

5. Bijzonder is dat de vraag ditmaal gesteld is door de Nederlandse rechter; op het gebied van het aanbestedingsrecht is dit slechts de vierde prejudiciële verwijzing vanaf de invoering van de eerste aanbestedingsrichtlijnen in 1971. De drie andere prejudiciële vragen zijn gesteld in: HvJ 20 september 1988, zaak C-31/87, Beentjes, ECLI:EU:C:1988:422; HvJ 10 november 1998, zaak C-360/96, BFI/ Arnhem, ECLI:EU:C:1998:525 en HvJ 9 december 2010, zaak C-568/08, Spijker, ECLI:EU:C:2010:751.

6. Ook wel 'aanbestedingsstukken'. Deze worden in art. 1.1 Aanbestedingswet 2012 gedefinieerd als: 'alle stukken die door de aanbestedende dienst (...) worden opgesteld of vermeld ter omschrijving of bepaling van onderdelen van de aanbesteding of de procedure'. Dit document dient ertoe dat alle gegevens, eisen en voorwaarden van de opdracht voor iedere geïnteresseerde onderneming op dezelfde wijze kenbaar zijn, ter waarborging van het gelijkheids- en transparantiebeginsel, zie verder hierna. mee zij vrijelijk gedurende het jaar kunnen reizen. De waarde van de opdracht, die een looptijd had van meer dan drie jaar, was ongeveer 60 miljoen euro per jaar. ${ }^{7}$

De aanbestedingsprocedure voor deze opdracht is nader omschreven in het 'beschrijvend document'. Dit document dient ertoe dat alle gegevens, eisen en voorwaarden van de opdracht voor iedere geinteresseerde onderneming op dezelfde wijze kenbaar zijn, ter waarborging van het gelijkheids- en transparantiebeginsel. ${ }^{8}$ Met betrekking tot de uitsluitingsgronden is in het document opgenomen dat ondernemers die zich inschrijven voor deze aanbestedingsprocedure, dienen te verklaren dat op hen geen van de gestelde uitsluitingsgronden van toepassing is. ${ }^{9}$ Meer specifiek dient een inschrijver bij deze aanbesteding te verklaren dat zijn onderneming of een bestuurder ervan geen ernstige fout in de uitoefening van zijn beroep heeft begaan. ${ }^{10}$ Van groot belang is verder dat in het beschrijvend document is opgenomen dat een inschrijving waarop een uitsluitingsgrond van toepassing is, terzijde wordt gelegd en niet in aanmerking komt voor verdere inhoudelijke beoordeling. ${ }^{11}$

Op 8 oktober 2012 laat VWS aan Connexxion, een van de deelnemers van de aanbestedingsprocedure, weten dat haar inschrijving op de tweede plaats is geëindigd en dat het voornemens is de opdracht te gunnen aan de Combinatie, bestaande uit Transvision, RMC en ZCN. Op 20 november 2012 legt de toenmalige Nederlandse Mededingingsautoriteit $(\mathrm{NMa})^{12}$ echter krachtens de Mededingingswet aan RMC en de BIOS-groep, waarvan $\mathrm{ZCN}$ deel uitmaakt, boetes op in zaken over taxivervoer in de regio Rotterdam in de periode van 17 april 2009 tot 1 maart 2011, vanwege ongeoorloofde afspraken tussen RMC en de BIOS-groep en RMC en een derde partij. Nu een overtreding van de mededingingsregels als een ernstige beroepsfout wordt aangemerkt, dit staat althans bij het Hof van Justitie niet meer ter

7. Connexxion Taxi Services, punt 12. Zie ook HR 27 maart 2016, ECLI:NL:HR:2015:757, r.o. 3.1

8. Het beschrijvend document kan worden gezien als (een onderdeel van) de 'aanbestedingsstukken', als gedefinieerd in art. 1.1 Aanbestedingswet 2012: 'alle stukken die door de aanbestedende dienst of het speciale-sectorbedrijf worden opgesteld of vermeld ter omschrijving of bepaling van onderdelen van de aanbesteding of de procedure'.

9. Hiervoor wordt gebruikgemaakt van de zogeheten 'Uniforme eigen verklaring aanbestedingen', die door de inschrijvers moet worden ingevuld en als verplichte bijlage aan de inschrijving moet worden toegevoegd.

10. Over de invulling van dit begrip 'ernstige beroepsfout', die is overgelaten aan de lidstaten, zie met name E.R. Manunza, 'Is een zwarte lijst van bouwbedrijven verenigbaar met het Europees recht?', Bouwrecht 2003 (40), p. 747-757; E.R. Manunza, 'Privatised Services and the Concept of "Bodies Governed by Public Law" in E.C. Directives on Public Procurement', European Law Review april 2003, afl. 28, p. 273-282. De uitsluitingsgrond 'ernstige beroepsfout' was ten tijde van het in de markt zetten van deze opdracht nog neergelegd in art. 45 Besluit aanbestedingsregels voor overheidsopdrachten (Bao); inmiddels is deze opgenomen in art. 2.87 lid 1 sub c Aanbestedingswet 2012.

11. Connexxion Taxi Services, punt 13. Zie ook HR 27 maart 2016, ECLI:NL:HR:2015:757, r.o. 3.1

12. Sinds 2013 is de NMa gefuseerd met de Consumentenautoriteit en de Onafhankelijke Post en Telecommunicatie Autoriteit (OPTA) en valt nu onder de Autoriteit Consument \& Markt (ACM). 
discussie, ${ }^{13}$ zou de Combinatie op grond van de aanbestedingsdocumenten moeten worden uitgesloten van de aanbestedingsprocedure.

VWS sluit de Combinatie echter niet uit. Het baseert die beslissing op de Nederlandse regelgeving, toen neergelegd in het Besluit aanbestedingsregels voor overheidsopdrachten (Bao) inclusief bijhorende toelichting op het Bao, die een aanbestedende dienst verplicht om alvorens tot uitsluiting over te gaan, eerst te toetsen of een uitsluiting in het concrete geval proportioneel is. ${ }^{14}$ $\mathrm{Nu}$ de Combinatie in deze zaak maatregelen had getroffen die haar betrouwbaarheid alsnog zouden aantonen, zou volgens VWS de uitsluiting van de Combinatie vanwege de mededingingsovertredingen in strijd zijn met het proportionaliteitsbeginsel. ${ }^{15}$

In het kort geding dat daarop door Connexxion wordt aangespannen, oordeelt de voorzieningenrechter dat het ministerie de Combinatie had moeten uitsluiten. ${ }^{16}$ Het gerechtshof daarentegen oordeelt dat een toets aan het proportionaliteitsbeginsel wel mocht plaatsvinden. ${ }^{17} \mathrm{De}$ Hoge Raad acht het dan voor zijn beslissing in het cassatieberoep van Connexxion nodig een drietal vragen (genummerd 1a, 1b en 2) aan het Hof van Justitie voor

13. In lagere instanties wordt dit nog wel ter discussie gesteld, zie: Gerechtshof Den Haag 3 september 2013, ECLI:NL:GHDHA: 2013:3723, r.o. 3.2 e.v. Inmiddels heeft het Hof van Justitie in HvJ 18 december 2014, zaak C-470/13, Generali-Providencia Biztosító, ECLI:EU:C:2014:2469, punt 35 expliciet gemaakt dat een overtreding van de mededingingsregels, met name wanneer de inbreuk met een geldboete is bestraft, valt onder het begrip 'ernstige beroepsfout'. Bovendien is deze grond nu in de nieuwe Richtlijn 2014/24/EU als aparte uitsluitingsgrond opgenomen in art. 57 lid 4 sub d, en geïmplementeerd in art. 2.87 lid 1 sub d Aanbestedingswet 2012

14. De verplichting was niet opgenomen in de wettekst van het Bao zelf, maar te vinden in de toelichting (Nota van toelichting bij de artikelen 45 en 46 van het Besluit van 16 juli 2005, houdende regels betreffende de procedures voor het gunnen van overheidsopdrachten voor werken, leveringen en diensten (Bao): '(...) De beoordeling of daadwerkelijk tot uitsluiting wordt overgegaan en voor hoe lang die uitsluiting geldt, dient gelet op de algemene uitganspunten van de aanbestedingsrichtlijnen steeds proportioneel en niet-discriminatoir te zijn. (...) Dit betekent ook dat er steeds sprake is van maatwerk, omdat elke aanbestedende dienst per opdracht moet nagaan of hij in het concrete geval (afhankelijk van de aard en omvang van de opdracht, de aard en omvang van de fraude en wat voor maatregelen het bedrijf inmiddels genomen heeft) een bedrijf moet uitsluiten.' In de conclusie van de A-G is te lezen dat de Nederlandse regering in antwoord op een vraag van het Hof van Justitie verklaart dat de nota van toelichting geen onderdeel vormt van de tekst van het Bao, ook al is zij samen met het besluit in hetzelfde Staatsblad gepubliceerd. De nota geeft als een considerans de redenen weer voor de vastgestelde tekst. Hoewel zij niet juridisch bindend is, heeft zij 'grote, rechtens relevante betekenis'. Het Hof van Justitie noemt dat deze nota van toelichting op zichzelf niet bindend is maar enkel in aanmerking dient te worden genomen voor de uitlegging van het Bao, Connexion Taxi Services, punt 42.

15. Zie voor de maatregelen (ook wel selfcleaning genoemd), de conclusie van de A-G bij de Hoge Raad, ECLI:NL:PHR:2014:2001, punt 3.28 en verder, waarin staat dat de Combinatie een complianceprogramma heeft geïmplementeerd en zich heeft ingezet om nieuwe overtredingen van de Mededingingswet te voorkomen. Zie verder: Connexxion Taxi Services, punt 17 en HR 27 maart 2016, ECLI:NL:HR:2015:757, r.o. 3.1.

16. Rb. Den Haag 17 april 2013, ECLI:NL:RBDHA:2013:BZ7736.

17. Gerechtshof Den Haag 3 september 2013, ECLI:NL:GHDHA: 2013:3723. te leggen, waarvan het Hof de laatste niet behandelt. ${ }^{18}$ Hieronder zal dan ook slechts worden ingegaan op de vraag of het Unierecht, in het bijzonder artikel 45 lid 2 van Richtlijn 2004/18/EG, zich ertegen verzet dat het nationale recht een aanbestedende dienst verplicht met toepassing van het evenredigheidsbeginsel, die in Nederland als het proportionaliteitsbeginsel wordt aangeduid, te beoordelen of daadwerkelijk uitsluiting moet volgen van een inschrijver die een ernstige beroepsfout heeft begaan (onderdeel a) en of het daarbij van belang is dat een aanbestedende dienst in de aanbestedingsvoorwaarden heeft opgenomen dat een inschrijving waarop een uitsluitingsgrond van toepassing is, terzijde wordt gelegd en niet in aanmerking komt voor verdere inhoudelijke beoordeling (onderdeel $\mathrm{b}$ ).

\section{Rol van de beginselen van gelijkheid, transparantie en evenredigheid bij het uitsluitingsstelsel}

De aanbestedingsregels vloeien voort uit de vrijverkeersbepalingen van het EU-Werkingsverdrag (VWEU), met name het vrij verkeer van goederen, vrijheid van vestiging, vrij verlenen van diensten, ${ }^{19}$ en zijn erop gericht de interne markt voor overheidsopdrachten tot stand te brengen. Beperkingen van deze internemarktdoelstelling moeten in dat licht zo veel mogelijk worden tegengegaan. Daarnaast spelen ook de uit de bovengenoemde verdragsartikelen afgeleide beginselen van gelijke behandeling, niet-discriminatie, wederzijdse erkenning, evenredigheid en transparantie daarin een belangrijke rol. ${ }^{20}$ In het bijzonder beogen de beginselen van nondiscriminatie, gelijke behandeling en transparantie te waarborgen dat voor alle ondernemingen in de EU-lidstaten een 'level playing field' bestaat om een overheidsopdracht te kunnen verkrijgen.

Ook het stelsel van uitsluitingsgronden in de aanbestedingsrichtlijnen dient in de eerste plaats te worden bezien in het licht van het bij de totstandkoming van de aanbestedingsrichtlijnen gestelde doel om de beslisruimte van aanbestedende diensten in de lidstaten te beperken en het level playing field voor inschrijvers te waar-

18. Deze (tweede) vraag gaat over de toetsingsintensiteit van de nationale rechter over de beslissing van de aanbestedende dienst in het concrete geval: moet die beslissing 'vol' worden getoetst of volstaat een 'marginale' toets? Het Hof van Justitie beantwoordt slechts de eerste prejudiciële vraag, nu het antwoord op de eerste vraag onder $1 \mathrm{~b}$, volgens het Hof de nationale rechter reeds de nodige gegevens verschaft om het aan hem voorgelegde geding te beslechten, zie: Connexion Taxi Services, punt 45 .

19. Zie de art. $26,28,49$ en 56 VWEU

20. Zie o.a. in Richtlijn 2014/24/EU, considerans overweging 1. Zie ook overweging 2 Richtlijn 2004/18/EG; onderhavig arrest is gewezen onder deze oude richtlijn. 
borgen. ${ }^{21}$ Ter voorkoming van een willekeurige toepassing en discriminatie tussen inschrijvers - en dus om het gelijkheids- en transparantiebeginsel te waarborgen - is dan ook voorzien in een systeem van uitsluiting van inschrijvers op basis van objectieve en niet-discriminerende bepalingen. ${ }^{22}$ Ondernemingen kunnen in beginsel alleen worden uitgesloten van een overheidsopdracht op basis van de in de richtlijn opgenomen gronden, die vervolgens ook op enge wijze moeten worden toegepast. ${ }^{23}$

Tevens dient een aanbestedende dienst die ervoor kiest bepaalde uitsluitingsgronden van toepassing te verklaren, deze in beginsel op grond van het gelijkheids- en transparantiebeginsel ook daadwerkelijk toe te passen. ${ }^{24}$ Tegelijkertijd vormt het uitsluiten van ondernemers ook een potentiële beperking van de interne markt, nu het eraan in de weg kan staan dat een zo groot mogelijk aantal inschrijvers aan aanbestedingsprocedures deelneemt. ${ }^{25}$ Hier speelt dan het evenredigheidsbeginsel in de rechtspraak van het Hof van Justitie een belangrijke rol in de afweging tussen de doelstelling van een zo groot mogelijke liberalisering van aanbestedingsprocedures, waarvoor de facultatieve uitsluitingsgronden een barrière kunnen vormen, en de doelstelling van algemeen belang, waardoor het stellen van uitsluitingsgronden gerechtvaardigd kan zijn, om zodoende de betrouwbaarheid, professionele integriteit en degelijkheid van de inschrijver te waarborgen. ${ }^{26}$ Daaruit volgt in beginsel dat uitsluiting nooit automatisch mag plaatsvinden, maar steeds getoetst dient te worden aan de concrete omstandigheden van het geval om vast te stellen of de specifieke situatie een uitsluiting rechtvaardigt.

21. Zoals o.a. ook genoemd door E.R. Manunza in de lezing 'Achieving smart, sustainable and inclusive growth through public procurement?', op de gezamenlijke bijeenkomst van de Nederlandse Vereniging voor Aanbestedingsrecht en de Vereniging voor Mededingingsrecht Enkele actuele aspecten van de relatie tussen aanbestedingsrecht en mededingingsrecht op 7 oktober 2016 te Utrecht. Zie ook reeds in o.a.: E.R. Manunza, 'Grote beslisruimte een oorzaak van corruptie', Cobouw 31 oktober 2014, p. 12; en zie verder: R.G.T. Bleeker en E.R. Manunza, 'De invloed van het Europees recht op het Nederlandse aanbestedingsrecht', in: A.S. Hartkamp, C.H. Sieburgh, L.A.D. Keus, J.S. Kortmann en M.H. Wissink (red.), De invloed van het Europese recht op het Nederlandse Privaatrecht. Bundel vanwege het Onderzoekscentrum voor Onderneming en Recht van de Radboud Universiteit Nijmegen (Serie Onderneming en recht, Deel 81-II, Bijzonder deel), Deventer: Kluwer 2014, p. 741-810.

22. O.a. in: E.R Manunza, 'Grote beslisruimte een oorzaak van corruptie', Cobouw 31 oktober 2014, p. 12.

23. Dit zogenoemde 'gesloten systeem' van uitsluitingsgronden volgt uit de rechtspraak van het Hof van Justitie. Zie o.a. HvJ 9 februari 2006, gevoegde zaken C-226/04 en C-228/04, La Cascina, ECLI:EU:C: 2006:94, punt 22; HvJ 16 december 2008, zaak C-213/07, Michaniki, ECLI:EU:C:2008:731, punt 42 en 43; HvJ 19 mei 2009, zaak C-538/07, Assitur, ECLI:EU:C:2009:317, punt 20. Zie ook: E.H. Pijnacker Hordijk, G.W. van der Bend en J.F. van Nouhuys, Aanbestedingsrecht. Handboek van het Europese en het Nederlandse Aanbestedingsrecht, Den Haag: Sdu Uitgevers 2009, p. 266.

24. Zie bijvoorbeeld: HvJ 6 november 2014, zaak C-42/13, Cartiere dell'Adda, ECLI:EU:C:2014:2345

25. Zie bijvoorbeeld: HvJ 10 juli 2014, zaak C-358/12, Consorzio Stabile Libor Lavori Pubblici, ECLI:EU:C:2014:2063, punt 29.

26. Aldus de A-G in punt 44 van zijn conclusie bij Connexxion Taxi Services. Die belangrijke rol noemt het Hof van Justitie overigens ook, in antwoord op prejudiciële vraag 1a, in Connexion Taxi Services, punt 32
Belangrijk te vermelden in dit opzicht is dat het proportionaliteitsbeginsel in het Nederlandse aanbestedingsrecht een belangrijke plaats heeft ingenomen. Reeds ten tijde van deze zaak was in de toelichting op het Bao, de wet waarin de richtlijn toen was omgezet, neergelegd dat de beoordeling of een uitsluiting dient plaats te vinden 'gelet op de algemene uitgangspunten van de aanbestedingsrichtlijnen steeds proportioneel en niet-discriminatoir [dient] te zijn'. ${ }^{27} \mathrm{Op}$ grond daarvan moet steeds in het concrete geval, aan de hand van de aard en omvang van de opdracht, de aard en omvang van de misdraging in samenhang met de maatregelen die het bedrijf inmiddels heeft genomen, worden vastgesteld of een uitsluiting gerechtvaardigd is. Inmiddels is het proportionaliteitsbeginsel in Nederland voor het gehele aanbestedingstraject verder uitgekristalliseerd in de Gids Proportionaliteit - een gids die is opgesteld in samenwerking met aanbestedende diensten en marktpartijen en die bij AMvB als verplicht te volgen richtsnoer is aangewezen. ${ }^{28}$ Bovendien is in de nieuwe aanbestedingsrichtlijn van 2014 ook meer nadruk gelegd op het proportionaliteitsbeginsel. ${ }^{29}$

Het Hof van Justitie bevestigt in dit arrest in antwoord op de eerste prejudiciële vraag onderdeel a dat lidstaten deze ruimte hebben, om in wetgeving op te nemen dat steeds met toepassing van het evenredigheidsbeginsel moet worden beoordeeld of een onderneming in een concreet geval al dan niet moet worden uitgesloten. Sinds het arrest La Cascina is het namelijk vaste rechtspraak van het Hof van Justitie dat artikel 45 lid 2 Richtlijn 2004/18/EG waarin de facultatieve uitsluitingsgronden waren opgenomen, ${ }^{30}$ niet voorziet in een uniforme toepassing van de daarin genoemde uitsluitingsgronden. ${ }^{31}$ Lidstaten mogen ervoor kiezen de uitsluitingsgronden in het geheel niet toe te passen of om deze op te nemen in de nationale regeling met een naargelang het geval strengere of minder strenge toepassing, in overeenstemming met de op nationaal niveau heersende juridische, economische of sociale overwegingen. Het Unierecht en in het bijzonder Richtlijn 2004/18/ EG laten dan ook, volgens het Hof van Justitie in onder-

27. De verplichting was niet opgenomen in de wettekst van het Bao zelf, maar te vinden in de nota van toelichting bij die wet, zie hierboven.

28. Zie art. 10 Aanbestedingsbesluit en zie: Gids proportionaliteit, eerste herziene versie april 2016, te raadplegen via: <www.pianoo.nl/ regelgeving/gewijzigde-aanbestedingswet-2012/herziene-gidsproportionaliteit>

29. Bijvoorbeeld verankerd in art. 18 lid 1 Richtlijn 2014/24/EU, maar in het bijzonder is in art. 57 met betrekking tot het uitsluitingsstelsel opgenomen dat elke ondernemer zijn betrouwbaarheid mag aantonen, meer daarover hierna; zie ook considerans Richtlijn 2014/24/EU, overwegingen 101 en 102.

30. Zowel ten tijde van het arrest La Cascina als ten tijde van onderhavige aanbesteding. Inmiddels zijn de facultatieve gronden neergelegd in art. 57 lid 4 van Richtlijn 2014/24/EU.

31. Connexion Taxi Services, punt 28 en zie: HvJ 9 februari 2006, gevoegde zaken C-226/04 en C-228/04, La Cascina, ECLI:EU:C:2006:94, punt 21-23 en HvJ 10 juli 2014, zaak C-358/12, Consorzio Stabile Libor Lavori Pubblici, ECLI:EU:C:2014:2063, punt 35 en 36. De toepassing van de uitsluitingsgronden, die betrekking hebben op de professionele integriteit, kredietwaardigheid of betrouwbaarheid van de gegadigden voor een opdracht, is in de richtlijn overgelaten aan de beoordeling van de lidstaten. 
havig arrest, de ruimte aan de lidstaten om in een nationale regeling de aanbestedende dienst te verplichten met toepassing van het evenredigheidsbeginsel te beoordelen of een gegadigde voor een overheidsopdracht die een ernstige beroepsfout heeft begaan, daadwerkelijk moet worden uitgesloten. ${ }^{32}$ Bovendien overweegt het Hof van Justitie ook kort dat uit overweging 2 van Richtlijn 2004/18/EG volgt dat het evenredigheidsbeginsel algemeen van toepassing is op procedures voor het plaatsen van overheidsopdrachten - dit is enigszins opvallend in het licht van het antwoord op onderdeel $b$ van de eerste prejudiciële vraag. ${ }^{33}$

\section{Voorrang van het gelijkheids- en transparantiebeginsel op het evenredigheidsbeginsel}

In antwoord op de eerste prejudiciële vraag, onderdeel $b$, gaat het Hof van Justitie vervolgens in op de vraag wat voorrang moet krijgen: de nationale regeling, althans de toelichting daarop, die vordert dat een toets aan het evenredigheidsbeginsel plaatsvindt alvorens wordt uitgesloten, óf de beginselen van gelijke behandeling en transparantie, nu in de aanbestedingsvoorwaarden voor de opdracht expliciet is opgenomen dat een inschrijver moet worden uitgesloten zonder dat een dergelijke toets aan het evenredigheidsbeginsel plaatsvindt. ${ }^{34}$ Hier komt een spanning tot uiting die kan ontstaan tussen de verschillende beginselen van het aanbestedingsrecht, en waarbij advocaat-generaal Campos Sánchez-Bordona en het Hof van Justitie in hun afweging daarvan tot een tegengestelde conclusie komen.

In de afweging tussen de beginselen komt het Hof van Justitie in deze zaak tot de conclusie dat aan het bepaalde in het aanbestedingsdocument voorrang moet worden gegeven boven de uit de Nederlandse regelgeving volgende toets aan het evenredigheidsbeginsel, omdat anders de beginselen van gelijkheid en transparantie zouden kunnen worden ondermijnd. ${ }^{35}$ In het aanbestedingsrecht is het nauwgezet in acht nemen van de aanbestedingsstukken immers van groot belang met het oog op het 'level playing field' voor alle (belangstellende) inschrijvers uit alle lidstaten. Om de gelijke behandeling en transparantie van de aanbestedingsprocedure te

32. Connexion Taxi Services, punt 32 en 33. Volgens het Hof van Justitie 'lijkt' een dergelijke evenredigheidstoetsing van de uitsluiting een versoepeling van de toepassing van de uitsluitingsgrond neergelegd in art. 45 lid sub d Richtlijn 2004/18/EG, als erkend in de eerder aangehaalde rechtspraak van het Hof van Justitie.

33. Connexion Taxi Services, punt 32

34. Zie ook de annotatie van E. van Dam en A. Drahmann bij HR 27 maart 2015, ECLI:NL:HR:2015:757, 'Prejudiciële vragen. Toepassing evenredigheidsbeginsel en marginale toetsing in aanbestedingsprocedure', $A B$ Rechtspraak Bestuursrecht 2015/277. Naast dat de verplichting tot een evenredigheidstoets zou volgen uit (de nota van toelichting bij) het Bao, kan volgens hen deze verplichting ook volgen uit art. 3:4 Awb jo. art. 3:14 BW en art. 3:1 lid 2 Awb.

35. Connexxion Taxi Services, punt 43 waarborgen moet de aanbestedende dienst dan ook nauwgezet de door hemzelf vastgestelde criteria in acht nemen, aldus het Hof van Justitie onder verwijzing naar het arrest Manova. ${ }^{36}$ Dit geldt dus ook voor de uitsluitingsgronden. ${ }^{37}$ Onder verwijzing naar het arrest Pizzo onderstreept het Hof van Justitie dat die beginselen in dit geval in gevaar komen, als een toetsing aan het evenredigheidsbeginsel plaatsvindt ondanks het bepaalde in de aanbestedingsdocumenten. ${ }^{38}$ Bepaalde belanghebbende ondernemers, die een beroepsfout hebben begaan die als ernstig aangemerkt zou kunnen worden, zouden namelijk op grond van het bepaalde in de aanbestedingsdocumenten kunnen besluiten wel een inschrijving in te dienen in de hoop te worden vrijgesteld van een uitsluiting op basis van het evenredigheidsbeginsel, terwijl andere ondernemers die zich in een vergelijkbare situatie bevinden, ervan af zouden kunnen zien omdat zij afgaan op de bewoordingen van het aanbestedingsdocument. ${ }^{39}$ Bovendien zou dit met name gevolgen hebben voor ondernemers uit andere lidstaten, volgens het Hof van Justitie, nu die minder bekend zullen zijn met de termen en toepassingsvoorwaarden van de relevante nationale regelingen. ${ }^{40}$

De advocaat-generaal komt daarentegen tot de conclusie dat van een dergelijke ondermijning van het transparantie- en gelijkheidsbeginsel geen sprake is, nu de evenredigheidstoets altijd van toepassing is en dus voor iedereen kenbaar: '( ...)zelfs indien het beschrijvend document niet uitdrukkelijk voorziet in de bevoegdheid van de aanbestedende dienst om de door de inschrijver begane fout te toetsen aan het evenredigheidsbeginsel, [moet] deze bevoegdheid als impliciet (...) worden

36. Connexion Taxi Services, punt 38 ; zie HvJ 10 oktober 2013, zaak C-336/12, Manova, ECLI:EU:C:2013:647, punt 40.

37. Zie ook HvJ 6 november 2014, zaak C-42/13, Cartiere dell'Adda, ECLI:EU:C:2014:2345. Zie verder: HR 7 december 2012, ECLI:NL:HR: 2012:BW9233 (Staat/KPN) waarin de Hoge Raad oordeelt dat de uitsluitingsgronden ondubbelzinnig en op niet voor misverstand vatbare wijze in de aanbestedingsdocumentatie moeten zijn vermeld: 'Een andere opvatting zou tot een willekeurige toepassing van de facultatieve uitsluitingsgronden kunnen leiden en daarmee een gelijke behandeling van de inschrijvers in gevaar kunnen brengen' (r.o. 3.6.3 en 3.6.4) en zie ook de annotatie van M.M. Fimerius en H.P.C. Goedegebure, 'Annotatie bij prejudiciële vragen van de Hoge Raad bij arrest van 27 maart 2015', Tijdschrift Aanbestedingsrecht 2015, nr. 4, p. 176-181, waarbij zij reeds de conclusie formuleren: 'Indien een dergelijke specifieke wettelijke evenredigheidsregeling niet bestaat, en ook het aanbestedingsdocument niet voorziet in een evenredigheidstoets, dient een aanbestedende dienst op grond van het transparantie- en gelijkheidsbeginsel (...) zeer terughoudend te zijn met het afzien van het toepassen van een gestelde norm op grond van het algemene evenredigheidsbeginsel'.

38. Connexion Taxi Services, punt 39 en 40; zie HvJ 2 juni 2016, zaak C-27/15, Pizzo, ECLI:EU:C:2016:404, punt 36 en daar aangehaalde rechtspraak.

39. Connexxion Taxi Services, punt 41

40. Connexxion Taxi Services, punt 42 
beschouwd. ${ }^{41}$ Bovendien baseert de advocaat-generaal zijn conclusie op de rechtspraak van het Hof van Justitie die de automatische uitsluiting van inschrijvers steeds heeft afgewezen zonder dat wordt bezien of de misdraging ook daadwerkelijk een uitsluiting rechtvaardigt - oftewel zonder dat een toets aan het evenredigheidsbeginsel plaatsvindt, waarover hierna meer. ${ }^{42}$ Iedere (buitenlandse) ondernemer had op grond van deze redenering kunnen weten dat ondanks het bepaalde in de aanbestedingsdocumenten nog een evenredigheidstoets zou plaatsvinden. Overigens noemt de advocaat-generaal ook nog dat het niet zo zou kunnen zijn, dat een aanbestedende dienst door middel van een bepaling in de aanbestedingsdocumenten van een wettelijke verplichting kan afwijken. ${ }^{43}$

\section{De automatische uitsluiting van ondernemers in het aanbestedingsrecht}

Uit de rechtspraak waarin het Hof van Justitie een automatische uitsluiting afwijst, blijkt inderdaad steeds dat het evenredigheidsbeginsel vereist dat de evenredigheid van de uitsluiting aan het concrete geval wordt getoetst. Reeds in de arresten Fabricom, Assitur en Serrantoni oordeelde het Hof van Justitie dat een onderneming steeds de kans dient te worden geboden aan te tonen dat de mededinging, ondanks de grond voor uitsluiting zoals betrokkenheid bij de voorbereiding van een opdracht, niet wordt geschaad. ${ }^{44}$ Wat betreft de facultatieve uitsluitingsgronden, met name de grond ernstige beroepsfout, heeft het Hof van Justitie de automatische uitslui-

41. Conclusie A-G in Connexxion Taxi Services, punt 49 en 50. De facultatieve uitsluitingsgronden zijn namelijk slechts effectief als aan de wettelijke voorwaarden voor hun toepassing is voldaan, zoals het beoordelen van de evenredigheid van een uitsluiting: 'De facultatieve uitsluitingsgronden zijn geen vrij zwevende grootheden, maar functioneren binnen vooraf vastgesteld wettelijk kader waaraan zij gebonden zijn: zij kunnen derhalve slechts effectief zijn wanneer aan de wettelijke voorwaarden voor hun toepassing is voldaan. Daartoe behoort onder meer dat het gedrag, wanneer het gaat om door inschrijvers begane inbreuken, wordt beoordeeld vanuit een oogpunt van evenredigheid.'

42. Zie Conclusie A-G in Connexxion Taxi Services, punt 54.

43. Zie Conclusie A-G in Connexxion Taxi Services, punt 59: '(...) het belang van het bestek (...) kan niet tot zulke proporties worden verheven dat daardoor de vereisten zoals die in elke lidstaat wettelijk zijn vastgesteld voor de aanbesteding van overheidsopdrachten zonder meer opzijgezet worden.' Daarbij moet hier wel in aanmerking worden genomen dat de verplichting volgde uit de nota van toelichting bij de wet.

44. HvJ 3 maart 2005, gevoegde zaken C-21/03 en C-34/03, Fabricom, ECLI:EU:C:2005:127, punt 35 en 36; HvJ 19 mei 2009, zaak C-538/07, Assitur, ECLI:EU:C:2009:317, punt 26 en 30 ; HvJ 23 december 2009, zaak C-376/08, Serrantoni, ECLI:EU:C:2009:808, m.n. punt 40. Zo oordeelt het Hof van Justitie in Assitur dat een regeling die is gebaseerd op een onweerlegbaar vermoeden dat de respectievelijke offertes van verbonden ondernemingen voor eenzelfde opdracht noodzakelijkerwijze onderling zijn beïnvloed, voorbijgaat aan het evenredigheidsbeginsel doordat deze ondernemingen de mogelijkheid wordt ontzegd aan te tonen dat er in hun geval geen sprake is van een reëel gevaar dat zich praktijken voordoen die de transparantie kunnen bedreigen en de mededinging tussen de inschrijvers kunnen vervalsen. ting afgewezen in de zaak Forposta in december 2012 - dus ná gunning van de opdracht in onderhavig arrest. ${ }^{45}$ In het arrest overweegt het Hof van Justitie dat een automatische uitsluiting van een inschrijver die zich heeft schuldig gemaakt aan een 'ernstige beroepsfout', de beoordelingsmarge kan overschrijden waarover de lidstaten beschikken. ${ }^{46}$ Het Hof van Justitie overweegt daarnaast dat het gedrag van een betrokken marktdeelnemer in concreto en individueel moet worden beoordeeld, nu een ernstige fout pas door een dergelijke toets kan worden vastgesteld. ${ }^{47}$

Toch is de afwijzing van de automatische uitsluiting in eerdere rechtspraak van het Hof van Justitie niet geheel eenduidig wanneer twee recente arresten van het Hof worden bezien, waarin een automatische uitsluiting bij de toepassing van de uitsluitingsgronden wel degelijk werd toegestaan. ${ }^{48}$ Daarbij is ook indicatief dat het Hof van Justitie in het onderhavige arrest, naast een verwijzing naar het belangrijke arrest La Cascina, verwijst naar de zaak Consorzio Stabile Libor Lavori Pubblici. ${ }^{49}$ In deze laatste zaak wordt een nationale regeling in overeenstemming met het Unierecht geacht, die bepaalt dat aanbestedende diensten bij het plaatsen van overheidsopdrachten verplicht zijn een inschrijver die een inbreuk heeft begaan op het gebied van de storting van socialezekerheidsbijdragen, uit te sluiten van de gunningsprocedure als het verschil tussen het verschuldigde en het gestorte bedrag groter is dan 100 euro en 5 procent van het verschuldigde bedrag. ${ }^{50}$ Een automatische uitsluiting neergelegd in een nationale regeling, zonder toetsing van de omstandigheden van het geval - in deze zaak was een bedrag van slechts 278 euro niet betaald wordt hier dus toegestaan. Ook in de recente zaak

45. HvJ 13 december 2012, zaak C-465/11, Forposta en ABC Direct Contact, ECLI:EU:C:2012:801. Zie ook Conclusie A-G in Connexxion Taxi Services, punt 52. Nu het Forposta-arrest is gewezen ná de gunning van de opdracht in onderhavig arrest, was deze nog niet kenbaar voor ondernemingen ten tijde van deze aanbesteding.

46. Forposta, punt 35. Deze bevoegdheid berust op art. 45 lid 2 Richtlijn 2004/18/EG.

47. Forposta, punt 31. Zie ook Conclusie A-G bij Connexxion Taxi Services, punt 52 en 53.

48. HvJ 10 juli 2014, zaak C-358/12, Consorcio Stabile Libor Lavori PublicCi, ECLI :EU:C:2014:2063 en HvJ 10 november 2016, zaak C-199/15, Ciclat, ECLI:EU:C:2016:853.

49. Zie Consorcio Stabile Libor Lavori Publicci; Connexxion Taxi Services, punt 28.

50. Het Hof van Justitie overweegt daartoe dat hoewel een dergelijke uitsluiting eraan in de weg kan staan dat een zo groot mogelijk aantal inschrijvers aan de aanbestedingsprocedures deelneemt en zodoende een beperking vormt van de art. 49 VWEU en 56 VWEU, deze beperking niettemin wordt gerechtvaardigd, nu het een legitiem doel zou dienen en niet in strijd is met het evenredigheidsbeginsel. De toets aan het evenredigheidsbeginsel houdt hier in dat de nationale regeling geschikt is om de verwezenlijking van dat doel (garanderen dat een inschrijver betrouwbaar, zorgvuldig en degelijk is en zich correct opstelt jegens zijn werknemers) te verzekeren en niet verder gaat dan noodzakelijk is om dat doel te bereiken (met betrekking daartoe overweegt het Hof van Justitie dat dit valt binnen de vrijheid van de lidstaten om de voorwaarden voor de toepassing van de uitsluitingsgronden te bepalen). Bovendien zou de regeling juist de gelijke behandeling en de rechtszekerheid van de inschrijvers garanderen, welk laatste beginsel een voorwaarde is voor de evenredigheid van een beperkende maatregel, zie Consorcio Stabile Libor Lavori Publicci, punt 31 
Ciclat $^{51}$ gaat het Hof van Justitie ver in het toestaan van een automatische uitsluiting. Hier werd een Consortium uitgesloten van een aanbestedingsprocedure, nu een van de daarbij horende bedrijven op het moment van inschrijven niet had voldaan aan zijn verplichtingen inzake het betalen van socialeverzekeringspremies. Het feit dat deze wanbetaling al was rechtgezet lang voor de ambtshalve controle werd uitgevoerd door de aanbestedende dienst en deze schending op het tijdstip van de gunning dus niet meer bestond, weerhield het Hof van Justitie niet te concluderen dat in dit geval wel degelijk uitsluiting moest plaatsvinden. ${ }^{52}$ Net als in de onderhavige zaak benadrukt het Hof van Justitie hier het belang van het 'level playing field': wanneer in de aanbestedingsdocumenten uitdrukkelijk is bepaald dat uitsluiting volgt als sprake is van niet-betaling van de bijdragen, moet daaraan worden vastgehouden. ${ }^{53}$ Daarbij moet wellicht wel rekening worden gehouden met het feit dat beide zaken zich afspelen in Italië - een land waar veel sprake is van corruptie - en het het niet betalen van socialezekerheidsbijdragen betreft.

\section{De ruime beoordelingsvrijheid bij de uitsluitingsgrond in het Connexxion Taxi Services-arrest}

Naast deze ontwikkeling in de rechtspraak van het Hof van Justitie om een automatische uitsluiting toe te laten - ondanks het evenredigheidsbeginsel - dient de afweging van het Hof ook geplaatst te worden tegen de achtergrond van de concrete situatie van dit arrest. De conclusie van het Hof van Justitie lijkt namelijk vooral te verklaren door het feit dat het gaat om de uitsluitingsgrond ernstige beroepsfout en de wijze waarop die uitsluitingsgrond in Nederland ten tijde van de feiten uit het arrest geregeld was.

De facultatieve uitsluitingsgrond ernstige beroepsfout is een open norm, waarvan de invulling en toepassing is overgelaten aan de lidstaten - binnen de kaders van het Unierecht. Een belangrijk arrest over de reikwijdte van die invulling en toepassing is het eerder genoemde Forposta-arrest, waarin het Hof van Justitie naast de afwijzing van een automatische uitsluiting, verduidelijkt dat het bij een ernstig beroepsfout moet gaan om een gedra-

51. HvJ 10 november 2016, zaak C-199/15, Ciclat, ECLI:EU:C:2016:853.

52. De nationale bepaling zou volgens het Hof van Justitie namelijk niet in strijd zijn met Aanbestedingsrichtlijn 2004/18/EG en de uit het VWEU voortvloeiende beginselen, zoals met name het redelijkheidsbeginsel. Onder verwijzing naar bovengenoemd arrest Consorzio Stabile Libor Lavori Pubblici overweegt het Hof van Justitie in Ciclat (punten 35 en 36) dat, nu art. 45 lid 2 Richtlijn 2004/18/EG niet in een uniforme toepassing van de facultatieve uitsluitingsgronden voorziet, deze bepaling de lidstaten ook niet verplicht om de aanbestedende diensten in dit opzicht beoordelingsvrijheid te laten. Het Hof van Justitie verwijst hier o.a. naar HvJ 10 oktober 2013, zaak C-336/12, Manova, ECLI:EU:C: 2013:647 en HvJ 6 november 2014, zaak C-42/13, Cartiera dell'Adda, ECLI:EU:C:2014:2345

53. Ciclat, punt $27 \mathrm{t} / \mathrm{m} 31$. ging van een zekere 'ernst'. ${ }^{54}$ In Nederland was ten tijde van de aanbesteding in het Connexxion Taxi Servicesarrest niet veel duidelijkheid over de invulling van de ernstige beroepsfout. ${ }^{55}$ Volgens het Gerechtshof Den Haag was het aan de aanbestedende diensten overgelaten om de uitsluitingsgrond nader in te vullen. ${ }^{56}$ Een overtreding van de mededingingsregels werd daarbij reeds langere tijd als ernstige beroepsfout aangemerkt. ${ }^{57}$ In de tussentijd is ook in rechtspraak van het Hof van Justitie expliciet gemaakt dat een dergelijke overtreding, met name wanneer de inbreuk met een geldboete is bestraft, als ernstige beroepsfout moet worden gezien ${ }^{58}$ en is deze grond nu in de nieuwe Richtlijn 2014/24/EU expliciet als uitsluitingsgrond opgenomen. ${ }^{59}$

Voordat het Hof van Justitie in Connexxion Taxi Services nadruk legt op het waarborgen van het gelijkheids- en transparantiebeginsel, overweegt het dan ook dat de Nederlandse regeling van het Bao aanbestedende diensten een ruime beoordelingsvrijheid toekent, zowel wat betreft de voorwaarden voor de toepassing van de facultatieve uitsluitingsgrond ernstige beroepsfout, alsook

54. HvJ 13 december 2012, zaak C-465/11, Forposta en ABC Direct Contact, ECLI:EU:C:2012:801.

55. Zie over de onduidelijkheid over deze uitsluitingsgrond, o.a.: E.R. Manunza, 'Enkele problemen bij de toepassing van het Europees aanbestedingsrecht in de Nederlandse (rechts)praktijk', SEW 2004, 8; E.R. Manunza, 'Is een zwarte lijst van bouwbedrijven verenigbaar met het Europees recht?', Bouwrecht 2003, nr. 40, p. 747-757; R.G.T. Bleeker en E.R. Manunza, 'De invloed van het Europees recht op het Nederlandse aanbestedingsrecht', in: A.S. Hartkamp, C.H. Sieburgh, L.A.D. Keus, J.S. Kortmann en M.H. Wissink (red.), De invloed van het Europese recht op het Nederlandse Privaatrecht. Bundel vanwege het Onderzoekscentrum voor Onderneming en Recht van de Radboud Universiteit Nijmegen (Serie Onderneming en recht, Deel 81-II, Bijzonder deel), Deventer: Kluwer 2014, p. 741-810. In lagere instanties wordt het aanmerken van mededingingsovertredingen als ernstige beroepsfout dan ook nog wel ter discussie gesteld. Zo stelt de Combinatie de vraag aan de orde of deze uitsluitingsgrond afdoende in de Nederlandse wetgeving is uitgewerkt en of in de aanbestedingsdocumentatie bij deze opdracht voldoende invulling aan het begrip 'ernstige beroepsfout' is gegeven. Naar het oordeel van het gerechtshof is het voor een redelijk geïnformeerde en oplettende inschrijver voldoende duidelijk dat in elk geval verboden kartelafspraken als ernstige beroepsfout kwalificeren, zie: Gerechtshof Den Haag 3 september 2013, ECLI:NL:GHDHA: 2013:3723, r.o. 3.2 e.v.

56. Volgens het gerechtshof in onderhavige zaak heeft de Nederlandse wetgever hierbij gedaan waartoe de richtlijn de lidstaten ruimte biedt: art. 45 lid 2 van Richtlijn 2004/18/EG integraal overnemen en het vervolgens aan de aanbestedende diensten overlaten om de uitsluitingsgronden nader in te vullen, zie: HR 27 maart 2015, ECLI:NL:HR: 2015:757 (Connexxion Taxi Services), r.o. 3.2.2. Het gerechtshof baseert zich daarbij op punt 23 van de considerans van de richtlijnen en het La Cascina-arrest (HvJ 9 februari 2006, gevoegde zaken C-226/04 en C-228/04, ECLI:EU:C:2006:94).

57. Zo was deze tot voor kort voor deze zaak neergelegd in art. 6 sub e van de Beleidsregels integriteit en uitsluiting bij aanbestedingen in BIBOBsectoren, Stcrt. 2004, 40, p. 15 (deze regeling is echter per oktober 2011 vervallen en gold dus niet meer ten tijde van deze aanbesteding). In de memorie van toelichting bij de Aanbestedingswet 2012 is de overtreding van de Mededingingswet echter wederom als zodanig aangemerkt: Kamerstukken // 2009/10, 32 440, nr. 3, p. 80.

58. Een overtreding van de mededingingsregels, met name wanneer de inbreuk met een geldboete is bestraft, valt onder het begrip 'ernstige beroepsfout' volgens HvJ 18 december 2014, zaak C-470/13, GeneraliProvidencia Biztosító, ECLI:EU:C:2014:2469, punt 35.

59. Zie art. 57 lid 4 sub d, en geïmplementeerd in art. 2.87 lid 1 sub d Aanbestedingswet 2012 . 
wat betreft de daadwerkelijke toepassing daarvan. ${ }^{60}$ In een dergelijke situatie is het van groot belang dat een clausule in de aanbestedingsstukken ondubbelzinnig is geformuleerd, zodat iedere behoorlijk geïnformeerde en normaal oplettende ondernemer in staat wordt gesteld kennis te nemen van de vereisten van de aanbestedende dienst en de voorwaarden van de opdracht, zodat zij dienovereenkomstig kunnen handelen. ${ }^{61}$ In het licht van het doel van het uitsluitingsstelsel, het tegengaan van willekeurige en discriminatoire uitsluitingen, dient met een ruime beoordelingsvrijheid dan ook zorgvuldig te worden omgegaan, nu het level playing field daarmee in gevaar kan komen. Dat zou kunnen verklaren waarom het Hof van Justitie hier zoveel nadruk legt op de beginselen van gelijkheid en transparantie.

Vraag blijft evenwel of een ernstige beroepsfout dan tot een automatische uitsluiting mag leiden, zonder toets aan het evenredigheidsbeginsel. Volgens het Hof van Justitie in onderhavige zaak kan de aanbestedende dienst daartoe besluiten, 'mits bij de beoordeling van de ernst van die fout het evenredigheidsbeginsel wordt geëerbiedigd'. ${ }^{62}$ Het lijkt er daarmee op dat het Hof van Justitie het mogelijk acht dat een aanbestedende dienst vooraf vaststelt dat voor deze specifieke opdracht overtredingen van de Mededingingswet waarvoor boetes zijn opgelegd, een zodanig 'ernstige' beroepsfout opleveren dat een automatische uitsluiting gerechtvaardigd is. ${ }^{63}$ Zoals uit het navolgende zal blijken is het belang van bovenstaande vraag echter beperkt, nu onder het huidige recht van Richtlijn 2014/24/EU van een automatische uitsluiting nooit meer sprake kan zijn.

\section{Betekenis Connexxion Taxi Services-arrest onder het huidige recht}

In onderhavig arrest komt het oordeel van het Hof van Justitie erop neer dat het evenredigheidsbeginsel onder het oude recht van Richtlijn 2004/18/EG niet vanzelfsprekend en impliciet van toepassing is op de uitsluitingsgronden. Een belangrijke vraag is of dit onder de nieuwe Richtlijn 2014/24/EU ook het geval is. Het Hof van Justitie heeft zijn beslissing in deze zaak in zijn eer-

60. Connexion Taxi Services, punt 35.

61. Connexion Taxi Services, punt 37.

62. Connexxion Taxi Services, punt 36.

63. Zie bijvoorbeeld ook: P.H.L.M. Kuypers, 'Aanbesteding en mededinging: een koningskoppel?', Tijdschrift Aanbestedingsrecht 2014, afl. 3, p. $128-135$, p. 134 , waar de auteur het een lacune van de regeling noemt, dat het proportionaliteitsbeginsel of de beoordelingsvrijheid van de aanbestedende dienst in de weg kan staan aan een uitsluiting op grond van mededingingsovertredingen. Daardoor zou de effectieve mededinging in een aanbesteding niet worden gewaarborgd. ste overweging daarbij strikt afgebakend naar het oude recht. ${ }^{64}$

In Richtlijn 2014/24/EU is in de regeling over de uitsluitingsgronden in artikel 57 lid 6 neergelegd dat elke ondernemer die verkeert in een situatie waarop een verplichte of facultatieve uitsluitingsgrond van toepassing is, de kans moet krijgen te bewijzen dat de maatregelen die hij heeft genomen voldoende zijn om zijn betrouwbaarheid aan te tonen ondanks de toepasselijke uitsluitingsgrond. ${ }^{65}$ Steeds als een uitsluitingsgrond van toepassing is, moet daarmee de ondernemer in ieder geval de kans worden geboden aan te tonen dat hij weer als integer kan worden aangemerkt. Als dat bewijs vervolgens toereikend wordt geacht, mag de ondernemer niet worden uitgesloten van een aanbestedingsprocedure. Op dat moment zou dan namelijk geen sprake meer zijn van een gerechtvaardigde uitsluiting. Bovendien wordt in hetzelfde artikellid ook uitgelegd welke deze zogenoemde 'selfcleaning-maatregelen' zijn en welke maatstaf aanbestedende diensten bij het beoordelen daarvan moeten hanteren. ${ }^{66}$ Daarnaast is wat betreft het niet betalen van socialezekerheidsbijdragen expliciet opgenomen dat een ondernemer niet wordt uitgesloten indien hij zijn verplichtingen (inmiddels) is nagekomen door verschuldigde belastingen of socialezekerheidsbijdragen, met inbegrip van lopende rente of boeten, te betalen of een bindende regeling tot betaling daarvan is aangegaan. ${ }^{67}$ Terugkomend op bovengenoemde Italiaanse zaken zou ook daar op grond van deze regeling onder het huidige recht geen automatische uitsluiting bij het niet-betalen van socialezekerheidsbijdragen meer mogen plaatsvinden - de ondernemer dient de kans te krijgen aan te tonen dat hij inmiddels als betrouwbaar kan worden aangemerkt.

Met dit wetgevend kader, dat is geimplementeerd in de Aanbestedingswet 2012, is deze verplichting nu duidelijk verankerd en zal dus kenbaar zijn voor alle geïnte-

64. Connexxion Taxi Services, punt 27. Overigens werd door sommigen deze verplichting om in het kader van de uitsluitingsgronden rekening te houden met de aanwezigheid van maatregelen in verband met 'selfcleaning' ook onder het oude recht al wel ingelezen, zie: S. Arrowsmith, $\mathrm{H}$. Prie $\beta$ en P. Friton, 'Self-cleaning as a defence to exclusion for misconduct - An emerging concept in EC Public Procurement Law?', Public Procurement Law Review 2009, 6, p. 259. Ook aangehaald in de annotatie van M.M. Fimerius en H.P.C. Goedegebure, 'Annotatie bij prejudiciële vragen van de Hoge Raad bij arrest van 27 maart 2015', Tijdschrift Aanbestedingsrecht 2015, nr. 4, p. 176-181.

65. Art. 57 lid 6 Richtlijn 2014/24/EU, geïmplementeerd in art. 2.87a Aanbestedingswet 2012 .

66. Het gaat dan om bewijs dat de ondernemer eventuele schade als gevolg van strafrechtelijke inbreuken of beroepsfouten heeft betaald of heeft toegezegd deze te zullen vergoeden, dat hij de feiten en omstandigheden heeft opgehelderd door actief mee te werken met de onderzoekende autoriteiten en dat hij concrete technische, organisatorische en personeelsmaatregelen heeft genomen die geschikt zijn om verdere strafrechtelijke inbreuken of fouten te voorkomen, zie art. 57 lid 6 Richtlijn 2014/24/EU, geïmplementeerd in art. 2.87a Aanbestedingswet 2012.

67. Art. 57 lid 2 Richtlijn 2014/24/EU, geïmplementeerd in art. 2.86 lid 5 jo. 2.87 lid 3 Aanbestedingswet 2012. 
resseerde - ook buitenlandse - inschrijvers. ${ }^{68}$ Goed betoogd kan worden dat deze wettelijke verplichting dan ook onder deze regelgeving voorrang heeft op elke voorwaarde die door de aanbestedende dienst in de aanbestedingsdocumenten is neergelegd. Toegepast op de situatie in Connexxion Taxi Services zou VWS op grond van deze regeling de Combinatie zelfs niet mogen uitsluiten van de aanbestedingsprocedure, wanneer de maatregelen die de Combinatie heeft genomen voldoende worden geacht om haar betrouwbaarheid aan te tonen. Bovendien kan op grond van deze bepaling in de richtlijn iedere belangstellende ondernemer weten dat aan elke ondernemer de mogelijkheid wordt geboden om zijn betrouwbaarheid alsnog aan te tonen, ondanks overtredingen van de Mededingingswet of een andere uitsluitingsgrond - en ondanks een eventueel in de aanbestedingsdocumenten opgenomen tegengestelde bepaling. ${ }^{69}$

\section{Conclusie}

In het aanbestedingsrecht is het level playing field voor alle ondernemingen van groot belang. De beginselen van gelijkheid en transparantie zijn daarbij zelfs van zo groot belang, dat het ertoe kan leiden dat daaraan voorrang moet worden gegeven boven het in acht nemen van het evenredigheidsbeginsel - althans onder het in deze zaak geldende uitsluitingsstelsel van Aanbestedingsrichtlijn 2004/18/EG. Met het oog op de wijzigingen in het uitsluitingsstelsel neergelegd in artikel 57 van Richtlijn 2014/24/EU lijkt het er echter op dat de spanning tussen de beginselen van gelijkheid en transparantie en het evenredigheidsbeginsel zoals in Connexxion Taxi Services, onder het huidige recht niet meer zal optreden. Door dwingend voor te schrijven dat aanbestedende diensten steeds de kans dienen te bieden aan een ondernemer zijn betrouwbaarheid aan te tonen als een uitsluitingsgrond van toepassing is, heeft de EU-wetgever een automatische toepassing van het evenredigheidsbeginsel voorgeschreven; een automatische uitsluiting kan dan ook niet meer plaatsvinden. Een bepaling in de aanbestedingsdocumenten dat een inschrijving terzijde wordt gelegd zonder verdere inhoudelijke beoordeling, wanneer sprake is van een uitsluitingsgrond, zal onder het huidige recht dan ook in strijd zijn met de Aanbestedingsrichtlijn.

68. Zie ook de annotatie van E. van Dam en A. Drahmann bij HR 27 maart 2015, ECLI:NL:HR:2015:757, 'Prejudiciële vragen. Toepassing evenredigheidsbeginsel en marginale toetsing in aanbestedingsprocedure', $A B$ Rechtspraak Bestuursrecht 2015/277. Hierin wordt gesteld dat een evenredigheidstoets in deze nieuwe regels wel voldoende duidelijk en kenbaar is voor 'elke redelijk geïnformeerde en oplettende inschrijver'.

69. Of die kenbaarheid ook geldt voor de evenredigheidstoets van art. 2.88 sub b Aanbestedingswet 2012, is op grond van dit arrest van het Hof van Justitie minder duidelijk. De bewoordingen van het Hof van Justitie suggereren namelijk dat een evenredigheidstoets ook niet kenbaar genoeg kan zijn wanneer deze in de wettelijke regeling zelf, in plaats van de toelichting daarop, zou zijn opgenomen, zie Connexxion Taxi Services, punt 42 . Of dit in de praktijk problemen op zal leveren is niet waarschijnlijk vanwege de bovengenoemde selfcleaning-regeling. 